\title{
Using Local Ecological Knowledge of Fishers to Reconstruct Abundance Trends of Elasmobranch Populations in the Strait of Sicily
}

OPEN ACCESS

Edited by:

Tomaso Fortibuoni, Institute for Environmental Protection and Research (ISPRA), Italy

Reviewed by:

loannis Giovos,

Sea Environmental Organisation for the Preservation of the Aquatic

Ecosystems, Greece

Eva Meyers,

Zoological Research Museum Alexander Koenig (LG), Germany

*Correspondence:

Francesco Colloca francesco.colloca@szn.it

Specialty section: This article was submitted to Marine Fisheries, Aquaculture

and Living Resources,

a section of the journal

Frontiers in Marine Science

Received: 05 March 2020 Accepted: 04 June 2020

Published: 30 June 2020

Citation:

Colloca F, Carrozzi V, Simonetti A and Di Lorenzo M (2020) Using Local

Ecological Knowledge of Fishers

to Reconstruct Abundance Trends of Elasmobranch Populations

in the Strait of Sicily.

Front. Mar. Sci. 7:508.

doi: 10.3389/fmars.2020.00508

\begin{abstract}
Francesco Colloca ${ }^{1,2 *}$, Virginia Carrozzi ${ }^{3}$, Andrea Simonetti ${ }^{4}$ and Manfredi Di Lorenzo ${ }^{3}$
${ }^{1}$ Department of Integrative Marine Ecology, Stazione Zoologica Anton Dohrn, Naples, Italy, ${ }^{2}$ Department of Biology and Biotechnology "Charles Darwin", Sapienza University of Rome, Rome, Italy, ${ }^{3}$ Institute for Marine Biological Resources and Biotechnologies, National Research Council (IRBIM-CNR), Mazara del Vallo, Italy, ${ }^{4}$ Department of Economics, Business and Statistics, University of Palermo, Palermo, Italy
\end{abstract}

Fishers "local ecological knowledge" (LEK) can be used to reconstruct long-term trends of species that are at very low biomass due to overfishing. In this study, we used historical memories of Sicilian fishers to understand their perception of change in abundance of cartilaginous fish in the Strait of Sicily over the last decades. We conducted interviews with 27 retired fishers from Mazara del Vallo harbor (SW Sicily) working in demersal fisheries, using a pre-defined questionnaire with a series of open and fixed questions related to the abundance of sharks and rays. The questionnaire included specific questions about the trends they perceived in catch or by-catch of cartilaginous fish abundance between the 1940s and 2000s compared to the present. Information was gathered for 18 species, including Carcharhinidae, mesopredatory demersal sharks (Squalidae, Hexanchidae, Centrophoridae, Oxynotidae, Triakidae, Scyliorhinidae, and Squatinidae) and batoids. Overall shark catches were perceived to have diminished since the early 1940s: about 95\% of fishers reported the decline of commercially important species (e.g., Mustelus spp.) and indicated species that could have been depleted or locally extinct (e.g., Squatina spp., Sphyrna lewini, Mustelus asterias, etc.). Our study shows that LEK of fishers can be beneficial for reconstructing long-term population trends of exploited species when traditional standard data on fisheries catch or species relative abundance from surveys is limited or only available for recent periods. The results obtained clearly indicate the rapid and alarming decline of elasmobranchs in the Strait of Sicily highlighting the need for urgent conservation measures to be adopted.

Keywords: local ecological knowledge, Chondrichthyes, Mediterranean Sea, fisheries sustainability, sharks and batoids

\section{INTRODUCTION}

Fishers have a rich knowledge of the resources and the environment in which they work, that is rarely utilized by decision-makers to provide valuable advice on the status of exploited populations, especially in areas where scientific data are scarce (Hind, 2015). Sharing of such traditional or local ecological knowledge (LEK) is being increasingly recognized as a way to achieve a more participative involvement of the community in the management 
of resources upon which they depend (Shephard et al., 2007; Fischer et al., 2015).

In particular, fishers LEK can be used to reconstruct historical abundance of marine populations, when data deficiency makes stock assessment difficult (Beaudreau and Levin, 2014). This is particularly the case for Mediterranean sharks and rays for which catch statistics are ambiguous or poorly defined (Cashion et al., 2019). Most of the available current knowledge on the status of populations is based on recent datasets covering the last 15-20 years, a period of very high fishing exploitation in which populations are presumably close to their lowest historical biomass (Colloca et al., 2013). The lack of inclusion of old data in the current stock assessment datasets increases the risk of providing an over-optimistic evaluation of the abundance of exploited species thus minimizing the importance of management (Barausse et al., 2014; Friedlander et al., 2015). Recent attempts to infer historical baselines and populations trends of Mediterranean elasmobranchs have shown worrisome rates of abundance decline (Ferretti et al., 2008, 2010; Damalas and Megalofonou, 2012; Fortibuoni et al., 2016; Colloca et al., 2017). The Mediterranean Sea is an elasmobranch-rich area with 88 species (Otero et al., 2019) while at the same time the area in the world with the highest proportion of threatened species (at least 53\%; Dulvy et al., 2016) due to overfishing, i.e., species classified by the International Union for Conservation of Nature (IUCN) as Vulnerable, Endangered and Critically Endangered (Dulvy et al., 2014). In addition, quite a large proportion of species (20\%) are classified as Data Deficient. The decline of Mediterranean elasmobranchs is largely due to the unregulated increase of fishing effort in the last decades which has rapidly reduced the distribution and abundance of populations. Old fishermen have witnessed this evolution of fisheries and the associated changes in the abundance and composition of fish catches across decades (Maynou et al., 2011). Their direct fishing experience can, therefore, be extremely important to understand how the abundance of species that are no longer targeted by fisheries due to their low abundance has changed over time. Although this information is often semi-quantitative it can be relevant to cover knowledge gaps and feed into the management process.

In this study, we used historical memories of Sicilian fishers to gain insight into the status of cartilaginous fish in the Strait of Sicily. This is probably the most important area for the conservation of Mediterranean elasmobranchs since it is characterized by large offshore banks (Di Lorenzo et al., 2017) still hosting viable populations of threatened species that have been severely depleted or gone extinct in other Mediterranean areas (Bradai et al., 2002, 2018). We conducted interviews with retired fishers from Mazara del Vallo harbor (SW Sicily) about the trends they perceived in the abundance of the most common commercial or by-catch species between the 1940s and 2000s in order to facilitate the estimation of eventual changes over time.

\section{METHOD}

We conducted interviews with 28 retired fishers from Mazara del Vallo harbor (SW Sicily, Figure 1) who had worked in both trawl and artisanal fisheries using a pre-defined questionnaire with a series of open and fixed questions focusing on abundances and catches of elasmobranch species, fishing techniques, vessel characteristics, and the location of fishing grounds.

Mazara del Vallo is the main fishing harbor in the region. It has hosted for decades the biggest trawl fleet of the Mediterranean Sea. The local fleet is mostly made up by big trawlers over $30 \mathrm{~m}$ in length operating long fishing trips (2-4 weeks) in different sectors of the Strait of Sicily and in the East Mediterranean Sea.

The interview process started with a preliminary contact with the two main associations of retired fishers of Mazara del Vallo, i.e., Associazione Casa del Pescatore, Associazione Nazionale Marinai d'Italia. The two associations provided a list of available fishers, preferentially skippers, who once interviewed were asked to indicate other retired fishers to be interviewed.

The survey focused on the period between the 1940s to the present divided into three-time segments: 1940-1960, 1961-1980, and 1981-2010 that roughly correspond to the different phases of development of Mediterranean fisheries, from a sustainable exploitation to a general over-exploitation of commercial fish stocks (Garcia, 2011). Fishers were asked to indicate their perceived abundance of the main species or taxa caught by demersal fisheries (see Table 1) in relation to the present (e.g., after 2010) according to four different categories: "less abundant," "the same," "more abundant (twice)," "much more abundant (three times)." Mustelus mustelus and Mustelus punctulatus were pooled in a single category (Mustelus spp.), separate from M. asterias. The first two species are morphologically very similar and often reported as the aggregate M. mustelus (Marino et al., 2018). On the other hand, M. asterias was usually distinguished by fishers from the other two species because of its body color and occurrence of small white spots. We also pooled the three angelsharks and the two guitarfish species occurring in the Mediterranean in two separate groups (i.e., Squatina spp. and Rhinobatos spp.).

To gather information about specific areas that can play an important role within the life cycles of the species, such as mating, parturition and feeding areas, we asked fishers about the best catch they ever remembered landing, the areas and the years in which these catches were made. Such information, gathered only for threatened species (Dulvy et al., 2016) was then displayed on maps to show areas that can be important for species conservation.

\section{RESULTS}

Interview respondents ranged in age from 48 to 86 years with a predominance of fishers over 70 years (61\%) (Supplementary Figure 1). They provided a total of 308 catch records for 19 taxa, that were the most commonly mentioned by fishermen during interviews. Species included mesopredatory demersal sharks (i.e., Squalidae, Hexanchidae, Centrophoridae, Oxynotidae, Triakidae, Scyliorhinidae, and Squatinidae), hammerhead sharks (smooth hammerhead, Sphyrna zygaena), and batoids (Table 1). 


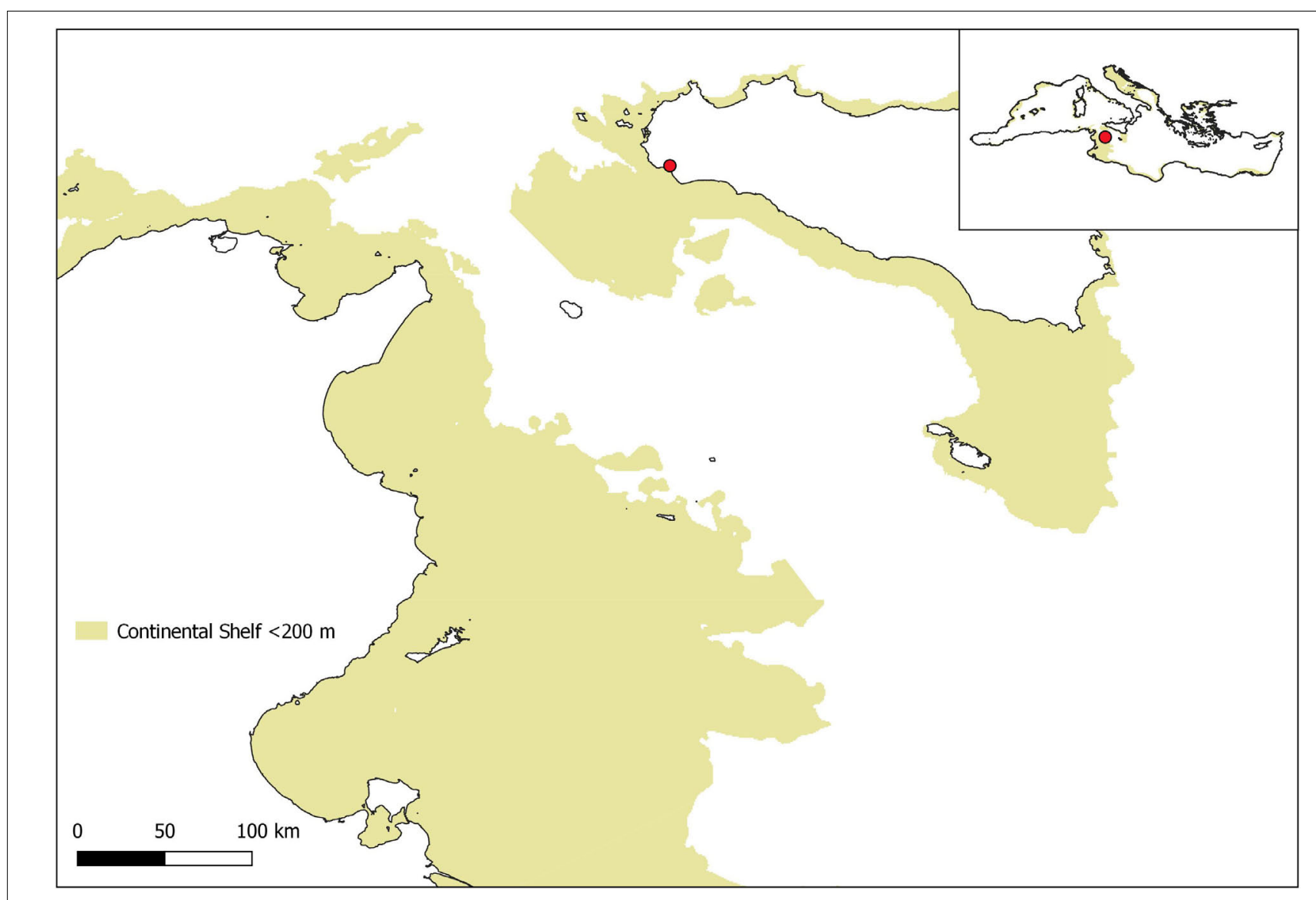

FIGURE 1 | Map of the Strait of Sicily showing the continental shelf (0-200 m depth, yellow background).

\section{Trend in Abundance}

The perceived trend in abundance of the shark species considered is shown in Figure 2. For all the species considered the abundance was reported to be at least three times higher in the first fishing period (1940-1960) and two to three times higher respectively compared to the present in the two following periods, 19611980 and 1981-2000. Only for smooth-hounds (Mustelus spp.), a small proportion of respondents $(<10 \%)$ did not indicate changes in species abundance since the 1960s. Species disappearance from at least some sectors of the area was reported for 5 Carcharhiniformes. All respondents considered that since the 1980s the smooth hammerhead was no longer present. A proportion of 75 and $67 \%$ of respondents reported the local extinction of the sharpnose sevengill shark (Heptranchias perlo) and starry smooth-hound (Mustelus asterias), respectively. For $22 \%$ of respondents also the tope shark (Galeorhinus galeus) and the bluntnose sixgill (Hexanchus griseus) were perceived to have disappeared from some fishing grounds. Angelsharks, longnose spurdog (Squalus blainville) and gulper shark (Centrophorus cf. uyato) were perceived to be three times less abundant compared to the present, also in the last time segment (1981-2000). In the same period, the angular roughshark (Oxynotus centrina) was considered two times less abundant than the present. All the interviewees considered the angelsharks to be extinct in the region with the last catches observed in the 1980s from a few poorly exploited fishing grounds.

Batoids were perceived to have generally declined by two or three times although at a lower rate compared to sharks with the exception of white skate Rostroraja alba, which was reported to have decreased by at least three times also in comparison to 19812000 and guitarfish (Rhinobatos spp.) (Figure 3). These species are nowadays considered as completely extinct from the Sicilian continental shelf. The last catches, up to 50 individuals per day, were obtained on the African shelf (SE Lampedusa). White skate, $R$. alba, was perceived by $50 \%$ of the interviewees to have disappeared from some traditional fishing grounds. The only species that were not reported to have declined since 1980-2000 are electric rays (Torpedo spp.), whilst stingrays (Dasyatidae), thornback ray (Raja clavata), brown ray (Raja miraletus) and longnose skate (Dipturus oxyrinchus) were perceived to be declining over time.

\section{High Catch Areas of Threatened Species}

Areas, where unusually high catches of the 11 threatened sharks were reported by fishers of Mazara del Vallo, are shown in Figure 4. Most of the observations were located in different fishing grounds of the continental shelf of Tunisia and Libya, whilst only a few records include the Sicilian shelf. Angelsharks 
TABLE 1 | List of the elasmobranchs species considered during the interview with the number of fishers providing data, the number of catch records and the maximum daily catch in kilograms or $\mathrm{n}$. individuals reported by species.

\begin{tabular}{|c|c|c|c|c|c|}
\hline \multirow{2}{*}{ Species } & \multirow{2}{*}{$\begin{array}{c}\text { Number } \\
\text { of } \\
\text { fishers }\end{array}$} & \multicolumn{3}{|c|}{$\begin{array}{c}\text { Number of } \\
\text { catch records }\end{array}$} & \multirow{2}{*}{$\begin{array}{c}\text { Max } \\
\text { reported } \\
\text { catch }\end{array}$} \\
\hline & & $\begin{array}{c}1940- \\
1960\end{array}$ & $\begin{array}{c}1961- \\
1980\end{array}$ & $\begin{array}{c}1981- \\
2000\end{array}$ & \\
\hline Centrophorus granulosus & 7 & 2 & 8 & 1 & $120 \mathrm{~kg}$ \\
\hline Heptranchias perlo & 10 & 1 & 8 & 1 & 4 ind \\
\hline Hexanchus griseus & 8 & 6 & 8 & & 6 ind \\
\hline Galeorhinus galeus & 10 & & 14 & 2 & 60 ind \\
\hline Mustelus asterias & 6 & 1 & 4 & 1 & $40 \mathrm{~kg}$ \\
\hline Mustelus sp. & 18 & 13 & 30 & 7 & 450 ind \\
\hline Oxynotus centrina & 4 & & 7 & 2 & - \\
\hline Schyliorhinus canicula & 7 & 6 & 9 & 2 & $480 \mathrm{~kg}$ \\
\hline Schyliorhinus stellaris & 5 & 1 & 8 & 2 & $120 \mathrm{~kg}$ \\
\hline Sphyrna zygaena & 4 & & 9 & 1 & 60 ind \\
\hline Squalus blainville & 17 & 3 & 18 & 4 & $2400 \mathrm{~kg}$ \\
\hline Squatina spp. & 13 & 20 & 18 & 4 & 150 ind \\
\hline Dasyatis pastinaca & 7 & 4 & 8 & 3 & $140 \mathrm{~kg}$ \\
\hline Dipturus oxyrinchus & 8 & 3 & 5 & 5 & $140 \mathrm{~kg}$ \\
\hline Raja clavata & 8 & 4 & 7 & 3 & $500 \mathrm{~kg}$ \\
\hline Rostroraja alba & 6 & 2 & 6 & 1 & 15 ind \\
\hline Raja miraletus & 10 & 3 & 7 & 3 & $100 \mathrm{~kg}$ \\
\hline Rhinobatos sp. & 6 & 2 & 10 & & 30 ind \\
\hline Torpedo spp. & 5 & 1 & 9 & 1 & $15 \mathrm{~kg}$ \\
\hline
\end{tabular}

were commonly targeted by Sicilian artisanal fishers until the 1960s using a specific fixed net called "squadrara." Until 1980 the maximum trawl catch was up to 150-200 individuals in a single haul. The last significant catches were reported for the early $1980 \mathrm{~s}$ and 1990s offshore from the western coasts of Libya. Guitarfish (Rhinobatos spp.) were found on coastal shelf areas along the SE Sicilian coasts until 1960-1980 (up to 10-20 individuals per fishing days). In the same period catches of 20-50 individuals per day were reported offshore the Tunisian coasts of Hammamet and SE of Lampedusa Island. The sharpnose sevengill shark is now rare in the area but also over the last decades the catch was made up of no more than 3-4 individuals from coastal fishing grounds close to Mazara harbor. O. centrina is a by-catch species discarded at sea that was generally poorly present in the catch, although two fishers reported extremely high catch of the species, 2-3 tons per day, from fishing grounds 50-60 m away from Mazara del Vallo during spring months. Very high catch of smooth-hounds (M. mustelus and $M$. punctulatus) up to 3 tons per day were reported by several fishers either on the Tunisian or Sicilian continental shelf. Adult aggregations, predominantly pregnant females were found mostly in April while juveniles were caught in September-October. The starry smooth-hound was generally perceived by fishers to have disappeared from the area. The last significant catches (maximum 0.1 ton/day) were reported until the 1970s. The other Triakidae species, the tope shark, was considered rare since the 1980s. The highest catches (40-60 individuals per day) were reported from Libyan fishing grounds during 1960-1980, especially in autumn. Last catches of the smooth hammerhead were declared to be obtained during the early 1980s. In 1960-1980 trawl by-catch of this shark was up to 20-60 individuals in single trawl hauls in winter, in particular on fishing grounds located SE of Lampedusa Island. Gulper shark was a common by-catch of trawlers exploiting fishing grounds on the continental slope. The reported maximum catches were up to 0.2 tons per day offshore the Libyan coasts. Finally, reported catch records of the two endangered batoids, the white skate and the common stingray, were from remote fishing grounds on the two sides of the Strait of Sicily. High catches of white skate, up to 0.2 tons per day, were reported as common until the 19601980s. The maximum catch of common stingray was of about 15-20 individuals per fishing day during 1960-1980.

\section{DISCUSSION}

In this study we have shown that the decline of elasmobranchs in the Strait of Sicily is perceived to have occurred for most of the main species caught by demersal fisheries, either sharks or rays. A reduction in the abundance of two or three times compared to the current situation was generally indicated also for the period 1981-2000 when the dimension of the trawl fleet was at its historical maximum.

Memories of old fishers are important to understand long-term changes in exploited populations, helping identify baselines against which modern populations can be benchmarked (McClenachan et al., 2012). As observed by Papworth et al. (2009) the transmission of knowledge and experience from longest-serving resource users to new generations is essential to avoid a "generational amnesia": e.g., as old observers leave the system, the population's perception of normality updates and past conditions are forgotten. Such shifting baseline syndrome (SBS) is common in fisheries and might reduce the usefulness of LEK in reconstructing trends in exploited populations (Sáenz-Arroyo et al., 2005). For instance, Maia et al. (2018) in a study on artisanal fisheries in São Tomé and Príncipe islands (Gulf of Guinea) found that fishers generations differed in their perceptions of declines over time, all of the very experienced fishers reported a decline, while only one-third of inexperienced fishers did so.

In the heavily exploited Mediterranean ecosystem, where deterioration of the natural environment is ongoing, new generations will probably view and accept the situation they find themselves in to be normal. This will result in a continued lowering of people's accepted norms for these environmental conditions and for this reason SBS is increasingly recognized as one of the fundamental obstacles to addressing a wide range of global environmental issues faced today (Soga and Gaston, 2018). In the Mediterranean Sea, where knowledge about the phenomenon remains incomplete and limited, older fishers have observed the development of industrial fisheries during the 1950s and 1960s, a period when the abundance and diversity of exploited species were presumably much higher than the present. The few attempts made so far to use LEK to understand trends in Mediterranean large marine fauna have shown that older fishers perceived a general temporal decline in the by-catch of elasmobranchs (Maynou et al., 2011; Giovos et al., 2019). 


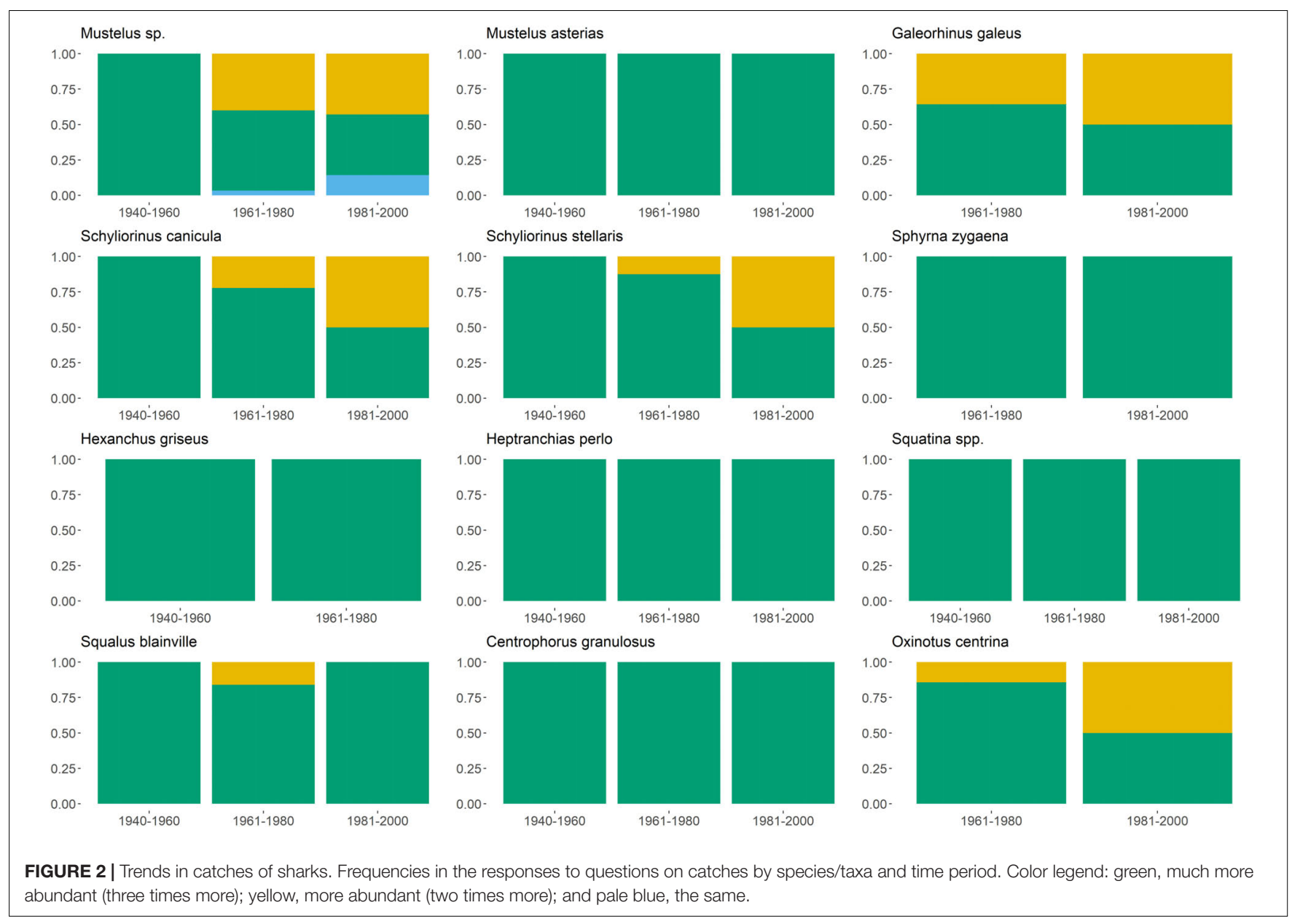

The history of Mazara trawl fishery is characterized by an almost linear increase of the fleet, from about 10 trawlers at the end of the World War II to about 290 trawlers at the end of 1990s, that was followed by a linear decrease since then (Supplementary Figure 2; Ben-Yehoyada et al., 2016). Knowledge on the status of the ecosystem during the period of fishery expansion is therefore extremely important to understand the impact of fishing itself and to identify baselines for fish stocks and exploited communities. In our study we made an effort to recover fishing memories of fishers who have experienced the status of a poorly exploited ecosystem. They witnessed a relevant decline of almost all the main elasmobranch species which were common by-catch of demersal fishing fleets, either trawlers or small-scale vessels, until 1960-1980. In particular, they observed the disappearance of species like angel sharks, hammerhead sharks, starry smoothhounds, tope shark, guitarfishes, and the reduction at very low levels of other species that are now considered as threatened by IUCN (Supplementary Table 1). A reduction in abundance was also perceived for common species, such as thornback ray, smooth-hounds, catshark, and others. This new knowledge is important to elucidate the ongoing status of sharks and rays in an area, the Strait of Sicily, that is probably the most important in the Mediterranean Sea for elasmobranch conservation (Bradai et al., 2018; Follesa et al., 2019). Here, differently from the rest of the basin, some sharks species are still targeted by artisanal fisheries although there is increasing evidence of a decline in their catch per unit of effort (Echwikhi et al., 2013; Saïdi et al., 2009). Information collected was also related to the areas where very high catches were observed. Most of the interviewees indicated the African shelf and in particular fishing grounds off the Libyan coasts to be aggregation areas for different species, thus confirming the importance of this area for the conservation of Mediterranean elasmobranchs. However, the fishers' local knowledge can be complemented and validated through well-designed studies, including tagging experiments, aimed at understanding if these areas are still relevant for the ecology of the investigated species and eventually ranking them for their importance for species conservation.

In our study we show that fishers' knowledge can be important in bridging the gap in our current understanding of the status of elasmobranchs populations, especially for those species that are no longer common and for which there are few scientific data. Although, the interview survey conducted in Mazara del Vallo could be expanded to cover other harbors and fishers' communities, our results support recent IUCN assessments for Mediterranean cartilaginous fish or studies based on historical catch data (e.g., Mediterranean smoothhounds, Colloca et al., 2017). They also indicate that recent 

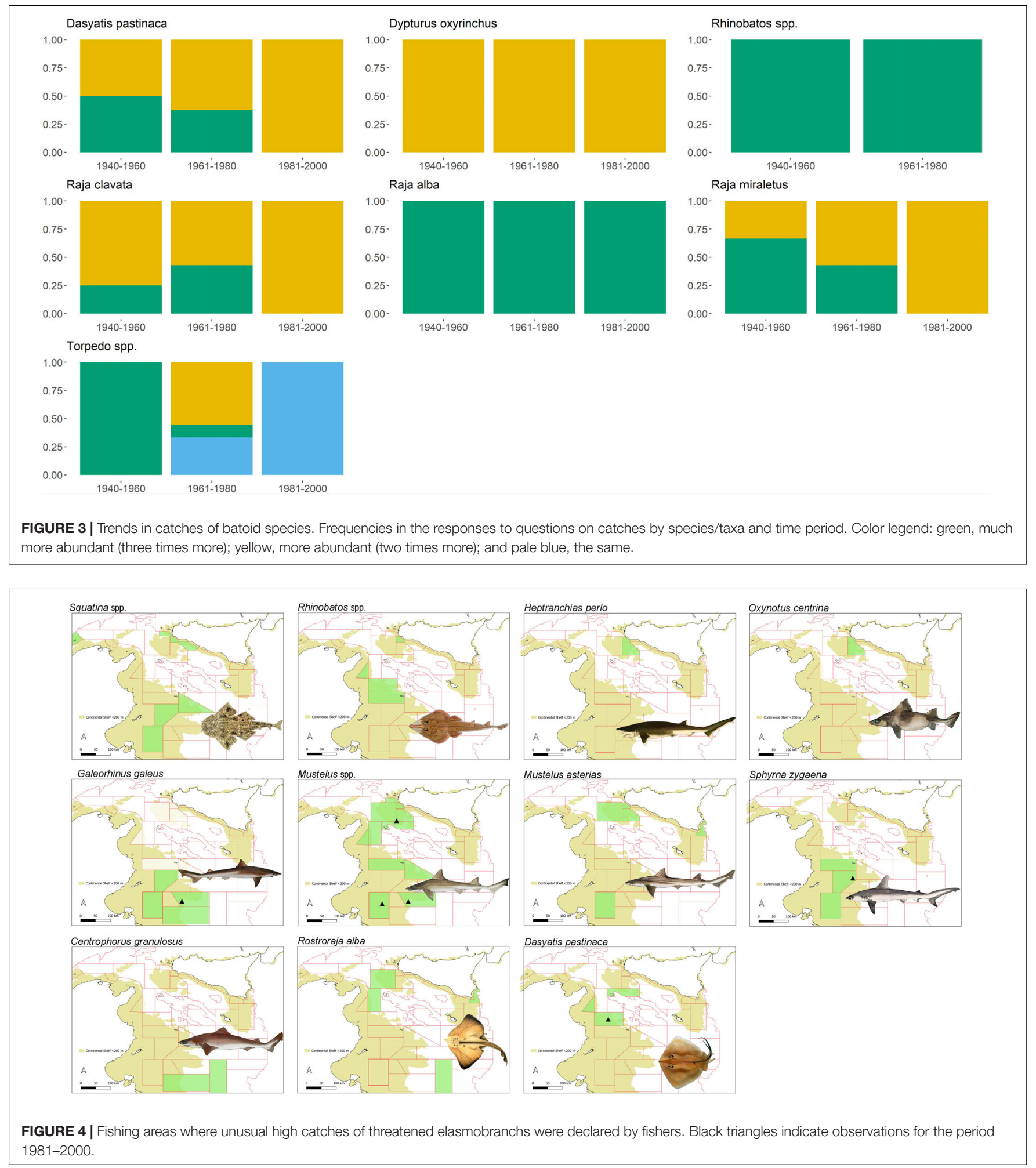

abundance data on elasmobranchs, collected during surveys and fisheries monitoring programs, are not very informative of the current status of populations. Survey data for instance, gathered during the last 30 years, usually show a low but rather stable species abundance without clear trends (Ragonese et al., 2013).
Combining different sources of scientific data with LEK can therefore be a step toward a better understanding of the impact of fishing on this important group of marine predators. Integration of social and natural science methodologies has gained attention over the past decade, with an increased recognition that 
LEK and scientific knowledge can be complementary, together with providing increased confidence in ecological information (Thornton and Scheer, 2012). This can be highly beneficial for Mediterranean cartilaginous fish which are under an increasing extinction risk due to the lack of appropriate conservation strategies aimed at minimizing the impact of fishing and rebuilding depleted populations.

\section{DATA AVAILABILITY STATEMENT}

The datasets generated for this study are available on request to the corresponding author.

\section{ETHICS STATEMENT}

The study was reviewed and approved by the Research Ethics and Integrity Committee of the Italian National Research Council (CNR), the institute for which authors conducted the research. The two fisher's associations participating in the study provided written informed consent to participate in this study.

\section{AUTHOR CONTRIBUTIONS}

FC and MD conceptualized the study. VC carried out interviews. AS and VC participated in the data analysis with FC. FC wrote the manuscript with contributions from VC, AS, and

\section{REFERENCES}

Barausse, A., Correale, V., Curkovic, A., Finotto, L., Riginella, E., Visentin, E., et al. (2014). The role of fisheries and the environment in driving the decline of elasmobranchs in the northern Adriatic Sea. ICES J. Mar. Sci. 71, 1593-1603. doi: 10.1093/icesjms/fst222

Beaudreau, A. H., and Levin, P. S. (2014). Advancing the use of local ecological knowledge for assessing data-poor species in coastal ecosystems. Ecol. Appl. 24, 244-256. doi: 10.1890/13-0817.1

Ben-Yehoyada, N., Cusumano, S., Pipitone, V., Polizzi, T., and Sanchez de la Sierra, R. (2016). L'economia della Pesca Di Mazara Del Vallo In Prospettiva Storica.[Mazara del Vallo's Fishing Economy In Historical Perspective]. Strumenti RES-Rivista Online Della Fondazione RES, VIII 1.

Bradai, M. N., Saidi, B., and Enajjar, S. (2018). "Overview on mediterranean shark's fisheries: impact on the biodiversity," in Marine Ecology - Biotic and Abiotic Interactions, Muhammet Türkoðlu, eds U. Önal, and A. Ismen (London: IntechOpen).

Bradai, M. N., Saïdi, B., Ghorbel, M., Bouaïn, A., and Guelorget, O. (2002). Observations sur les requins du golfe de Gabès (Tunisie méridionale, Méditerranée centrale). Mésogée 60, 61-77.

Cashion, M. S., Bailly, N., and Pauly, D. (2019). Official catch data underrepresent shark and ray taxa caught in mediterranean and black sea fisheries. Mar. Policy 105, 1-9. doi: 10.1016/j.marpol.2019. 02.041

Colloca, F., Cardinale, M., Maynou, F., Giannoulaki, M., Scarcella, G., Jenko, K., et al. (2013). Rebuilding Mediterranean fisheries: a new paradigm for ecological sustainability. Fish Fish. 14, 89-109. doi: 10.1111/j.1467-2979.2011.00453.x

Colloca, F., Enea, M., Ragonese, S., and Di Lorenzo, M. (2017). A century of fishery data documenting the collapse of smooth-hounds (Mustelus spp.) in the mediterranean Sea. Aquat. Conserv. Mar. Freshw. Ecosyst. 27, 1145-1155. doi: 10.1002 aqc. 2789
MD. All authors contributed to the article and approved the submitted version.

\section{FUNDING}

This publication has emanated from research supported by the National Research Council, Institute for Marine Biological Resources, and Biotechnologies of Mazara del Vallo and funded by the Italian National flagship programme RITMARE.

\section{ACKNOWLEDGMENTS}

We thank fishers of the Associazione Casa del Pescatore and Associazione Nazionale Marinai d'Italia of Mazara del Vallo, Italy, for their availability and enthusiasm shown during the interviews. We thank Katie E. Hogg for improving the English of this manuscript (https://katehogg.org/) and Danilo Scannella for providings maps of the fishing grounds of Mazara del Vallo trawl fleet.

\section{SUPPLEMENTARY MATERIAL}

The Supplementary Material for this article can be found online at: https://www.frontiersin.org/articles/10.3389/fmars. 2020.00508/full\#supplementary-material

Damalas, D., and Megalofonou, P. (2012). Occurrences of large sharks in the open waters of the southeastern Mediterranean Sea. J. Nat. Hist. 46, 2701-2723. doi: 10.1080/00222933.2012.716864

Di Lorenzo, M., Sinerchia, M., and Colloca, F. (2017). The North sector of the strait of sicily: a priority area for conservation in the Mediterranean Sea. Hydrobiologia. 821, 235-253. doi: 10.1007/s10750-017-3389-7

Dulvy, N. K., Allen, D. J., Ralph, G. M., and Walls, R. H. L. (2016). The Conservation Status Of Sharks, Rays And Chimaeras In The Mediterranean Sea [Brochure]. Malaga: IUCN.

Dulvy, N. K., Fowler, S. L., Musick, J. A., Cavanagh, R. D., Kyne, M., Harrison, L. R., et al. (2014). Extinction risk and conservation of the world's sharks and rays. eLife 3:e0590. doi: 10.7554/eLife.00590

Echwikhi, K., Saidi, B., Bradai, M. N., and Bouain, A. (2013). Preliminary data on elasmobranch gillnet fishery in the Gulf of Gabès, Tunisia. J. Appl. Ichthyol. 29, 1080-1085. doi: 10.1111/jai.12022

Ferretti, F., Myers, R. A., Serena, F., and Lotze, H. K. (2008). Loss of large predatory sharks from the Mediterranean Sea. Conserv. Biol. 22, 952-964. doi: 10.1111/j. 1523-1739.2008.00938.x

Ferretti, F., Worm, B., Britten, G. L., Heithaus, M. R., and Lotze, H. K. (2010). Patterns and ecosystem consequences of shark declines in the ocean. Ecol. Lett. 13, 1055-1071. doi: 10.1111/j.1461-0248.2010.01489.x

Fischer, J., Jorgensen, J., Josupeit, H., and Kalikoski, D. C. (2015). Fishers'; Knowledge And The Ecosystem Approach To Fisheries: Applications, Experiences And Lessons In Latin America. FAO fisheries and aquaculture technical Paper no: 591. Rome: FAO.

Follesa, M. C., Marongiu, M. F., Zupa, W., Bellodi, A., Cau, A., Cannas, R., et al. (2019). Spatial variability of chondrichthyes in the northern mediterranean. Sci. Mar. 83, 81-100. doi: 10.3989/scimar.04998.23A

Fortibuoni, T., Borme, D., Franceschini, G., Giovanardi, O., and Raicevich, S. (2016). Common, rare or extirpated? Shifting baselines for common angelshark, Squatina squatina (Elasmobranchii: Squatinidae), in the Northern Adriatic Sea 
(Mediterranean Sea). Hydrobiologia 772, 247-259. doi: 10.1007/s10750-0162671-4

Friedlander, A. M., Nowlis, J. S., and Koike, H. (2015). "Improving fisheries assessments using historical data: stock status and catch limits," in Marine Historical Ecology in Conservation: Applying the Past to Manage for the Future, eds J. N. Kittinger, L. McClenachan, K. B. Gedan, and L. K. Blight (Oakland: University of California Press), 91-118. doi: 10.1525/9780520959606-009

Garcia, S. M. (2011). Long-Term Trends In Small Pelagic And Bottom Fisheries In The Mediterranean : 1950-2008. Valbonne: Plan Bleu.

Giovos, I., Stoilas, V. O., Al-Mabruk, S. A., Doumpas, N., Marakis, P., Maximiadi, M., et al. (2019). Integrating local ecological knowledge, citizen science and long-term historical data for endangered species conservation: additional records of angel sharks (Chondrichthyes: Squatinidae) in the Mediterranean Sea. Aquat. Conserv. 29, 881-890. doi: 10.1002/aqc. 3089

Hind, E. J. (2015). A review of the past, the present, and the future of fishers' knowledge research: a challenge to established fisheries science. ICES J. Mar. Sci. 72, 341-358. doi: 10.1093/icesjms/fsul69

Maia, H. A., Morais, R. A., Siqueira, A. C., Hanazaki, N., Floeter, S. R., and Bender, M. G. (2018). Shifting baselines among traditional fishers in São Tomé and Príncipe islands, Gulf of Guinea. Ocean Coast Man. 154, 133-142. doi: 10.1016/j.ocecoaman.2018.01.006

Marino, I. A. M., Finotto, L., Colloca, F., Di Lorenzo, M., Gristina, M., Farrell, E. D., et al. (2018). Resolving the ambiguities in the identification of two smoothhound sharks (Mustelus mustelus and Mustelus punctulatus) using genetics and morphology. Mar. Biodiver. 48, 1551-1562. doi: 10.1007/s12526-017-0701-8

Maynou, F., Sbrana, M., Sartor, P., Maravelias, C., Kavadas, S., Damalas, D., et al. (2011). Estimating trends of population decline in long-lived marine species in the Mediterranean Sea based on fishers' perceptions. PLoS One 6:e21818. doi: 10.1371/journal.pone.0021818

McClenachan, L., Ferretti, F., and Baum, J. K. (2012). From archives to conservation: why historical data are needed to set baselines for marine animals and ecosystems. Conserv. Lett. 5, 349-359. doi: 10.1111/j.1755-263X.2012. 00253.x

Otero, M., Serena, F., Gerovasileiou, V., Barone, M., Bo, M., Arcos, J. M., et al. (2019). Identification Guide Of Vulnerable Species Incidentally Caught In Mediterranean Fisheries. Malaga: IUCN.
Papworth, S. K., Rist, J., Coad, L., and Milner-Gulland, E. J. (2009). Evidence for shifting baseline syndrome in conservation. Conserv. Lett. 2, 93-100. doi: 10.1111/j.1755-263x.2009.00049.x

Ragonese, S., Vitale, S., Dimech, M., and Mazzola, S. (2013). Abundances of Demersal Sharks and Chimaera from 1994-2009 scientific surveys in the central mediterranean Sea. PLoS One 8:e074865. doi: 10.1371/journal.pone.007 4865

Sáenz-Arroyo, A., Roberts, C. M., Torre, J., Cariño-Olvera, M., and EnríquezAndrade, R. R. (2005). Rapidly shifting environmental baselines among fishers of the Gulf of California. Proc. R. Soc. B Biol. Sci. 272, 1957-1962. doi: 10.1098/ rspb.2005.3175

Saïdi, B., Bradaï, M. N., and Bouaïn, A. (2009). Reproductive biology and diet of Mustelus punctulatus (Risso, 1826) (Chondrichthyes: Triakidae) from the Gulf of Gabès, central Mediterranean Sea. Sci. Mar. 73, 249-258. doi: 10.3989/scimar. 2009.73n2249

Shephard, S., Connolly, P., Hareide, N. R., and Rogan, E. (2007). Establishing stakeholder connections for management of the Irish orange roughy fishery. ICES J. Mar. Sci. 64, 841-845. doi: 10.1093/icesjms/fs 1034

Soga, M., and Gaston, K. J. (2018). Shifting baseline syndrome: causes, consequences, and implications. Front. Ecol. Environ. 16, 222-230. doi: 10.1002/ fee. 1794

Thornton, T. F., and Scheer, A. M. (2012). Collaborative engagement of local and traditional knowledge and science in marine environments: a review. Ecol. Soc. 17:8. doi: 10.5751/ES-04714-170308

Conflict of Interest: The authors declare that the research was conducted in the absence of any commercial or financial relationships that could be construed as a potential conflict of interest.

Copyright (c) 2020 Colloca, Carrozzi, Simonetti and Di Lorenzo. This is an openaccess article distributed under the terms of the Creative Commons Attribution License (CC BY). The use, distribution or reproduction in other forums is permitted, provided the original author(s) and the copyright owner(s) are credited and that the original publication in this journal is cited, in accordance with accepted academic practice. No use, distribution or reproduction is permitted which does not comply with these terms. 